\section{Reading the book of death}

\begin{abstract}
Studies of mass extinctions tend to emphasize the sheer scope of
\end{abstract} the carnage. But subtle differences between the species that died and those that survived can be crucial, finds Nick Lane.

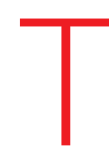

he extinction at the end of the Permian period, some 251 million years ago, is the most fascinating mass-murder mystery in Earth's history. Simply put, a party or parties unknown killed off up to $96 \%$ of all species then alive. Palaeontologists and Earthsystem scientists have suggested any number of possible culprits, from a comet or asteroid collision to a collapse of the ozone layer, from a dramatic suite of volcanic eruptions to ocean waters bubbling with sulphurous fumes.

Given that the evidence for an impact, although championed by some, seems sketchy and inconclusive to the majority, the most dramatic of these suspects is volcanism - the sequence of eruptions that gave rise to the basalts of the Siberian Traps. The scale of the eruptions was vast, with something like 3 million cubic kilometres of basalt flowing on to the surface, and the main lava flows took place at almost exactly at the same time as the end-Permian extinction itself, give or take a few hundred thousand years. The vast clouds of gas and ash they spewed out look like the smoke from a very large gun indeed ${ }^{1}$.

But if the erupting traps look increasingly like the trigger for the great die-off, how did they actually do their damage? The fiery birth of a small continent's worth of new landscape can change everything from the brightness of the sky to the chemistry of the oceans. How can scientists work out which of these effects were inconveniences, and which were fatal?

One answer is to study not the volcanoes, nor their victims, but the creatures that survived. A mortality rate of $96 \%$ sounds pretty indiscriminate - but recent physiological comparisons between the creatures that died and those that survived reveal intriguing patterns ${ }^{2}$. And these patterns do not just provide clues as to how the great dying actually unfurled. They also reveal how the extinctions at the end of the Permian period shaped the subsequent history of the world that the survivors inherited.

Until recently, perhaps the most popular 'kill mechanism' evoked for the extinction was global warming ${ }^{3}$. Volcanic carbon dioxide, so the story goes, raised temperatures enough to destabilize vast reserves of methane hydrates in the sea floor, pumping temperatures up further. But although there's little question that global temperatures rose at the end of the Permian by as much as $6^{\circ} \mathrm{C}$, there are problems with this picture.

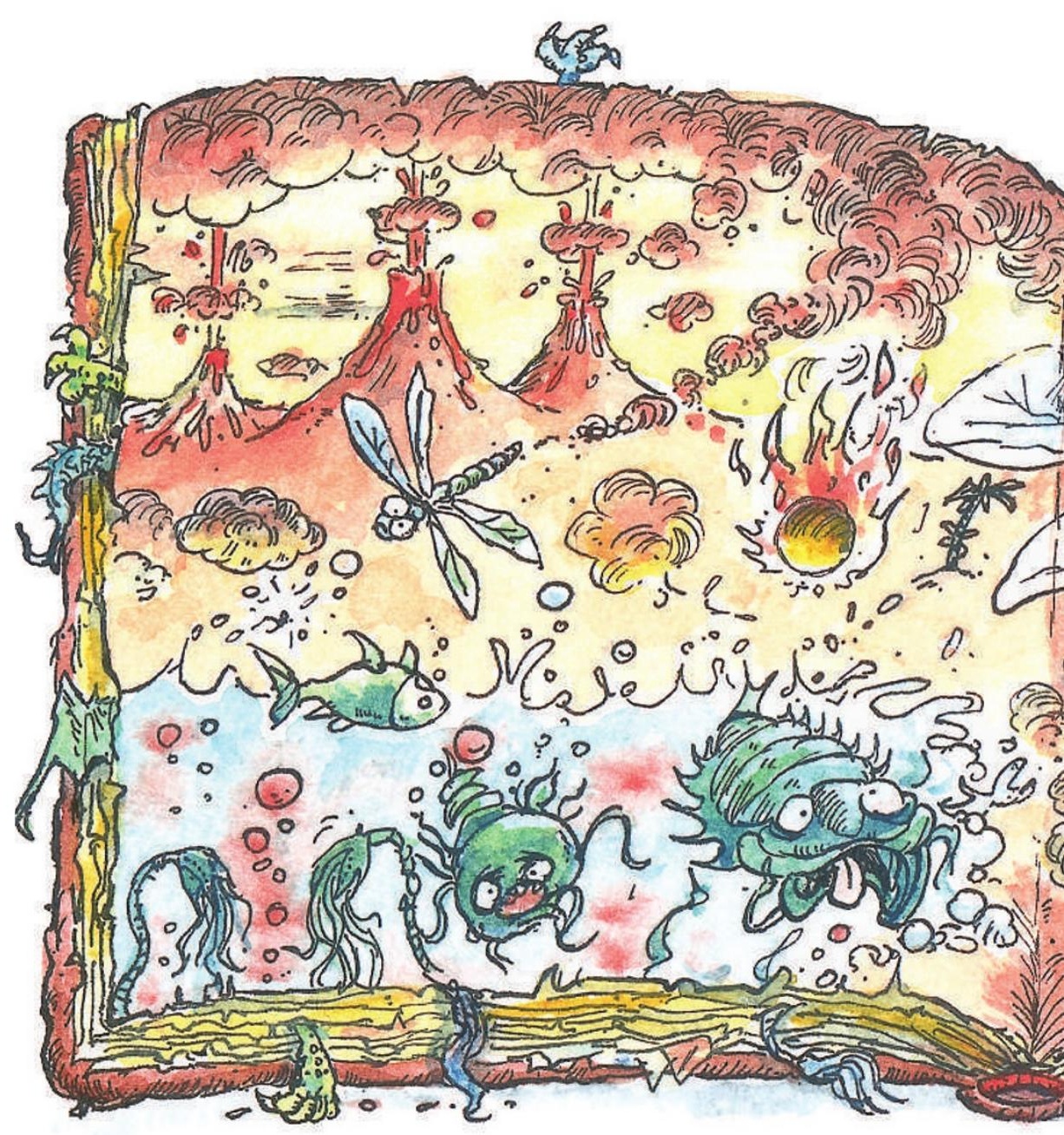

Among the things to go extinct at the end of the Permian are a lot of plants. There are plausible arguments as to how temperature could kill off animals - for example, it would force a higher metabolic rate on them, requiring an increase in their calorie intake that they might simply not have been able to satisfy. But there's no obvious reason why such heat would damage plants. What's more, the physiology of the survivors doesn't fit the story. Animals that seem to have started off with higher metabolic rates suffered less than those with slow metabolisms. Other things being equal, you might expect animals that are already generating more heat in their own bodies to do worse when things heat up further.

Another possible kill mechanism is a collapsed ozone layer. Mutant pollen and spores in sediments from the time of the extinction hint at an increase in ultraviolet levels brought about by a dearth of ozone. David Beerling, a plant physiologist who concentrates on palaeoclimate issues at the
"Animals have too many places to hide on land, and in the oceans they could easily escape ozone collapse." - David Beerling University of Sheffield, UK, says his eyes were opened to this risk when he learned that a NASA aircraft flying through the plume above the 2000 Hekla eruption in Iceland showed substantial amounts of hydrochloric acid had been injected directly into the stratosphere. Simulations by Beerling and his colleagues at Sheffield and the University of Cambridge, UK, suggest that the Siberian Traps could have removed $70 \%$ of the ozone shield from the Northern Hemisphere, enough to do serious environmental damage 4 .

Even so, Beerling doubts that an ozone collapse was responsible for the mass extinction: "Animals have too many places to hide on land, and in the oceans they could 


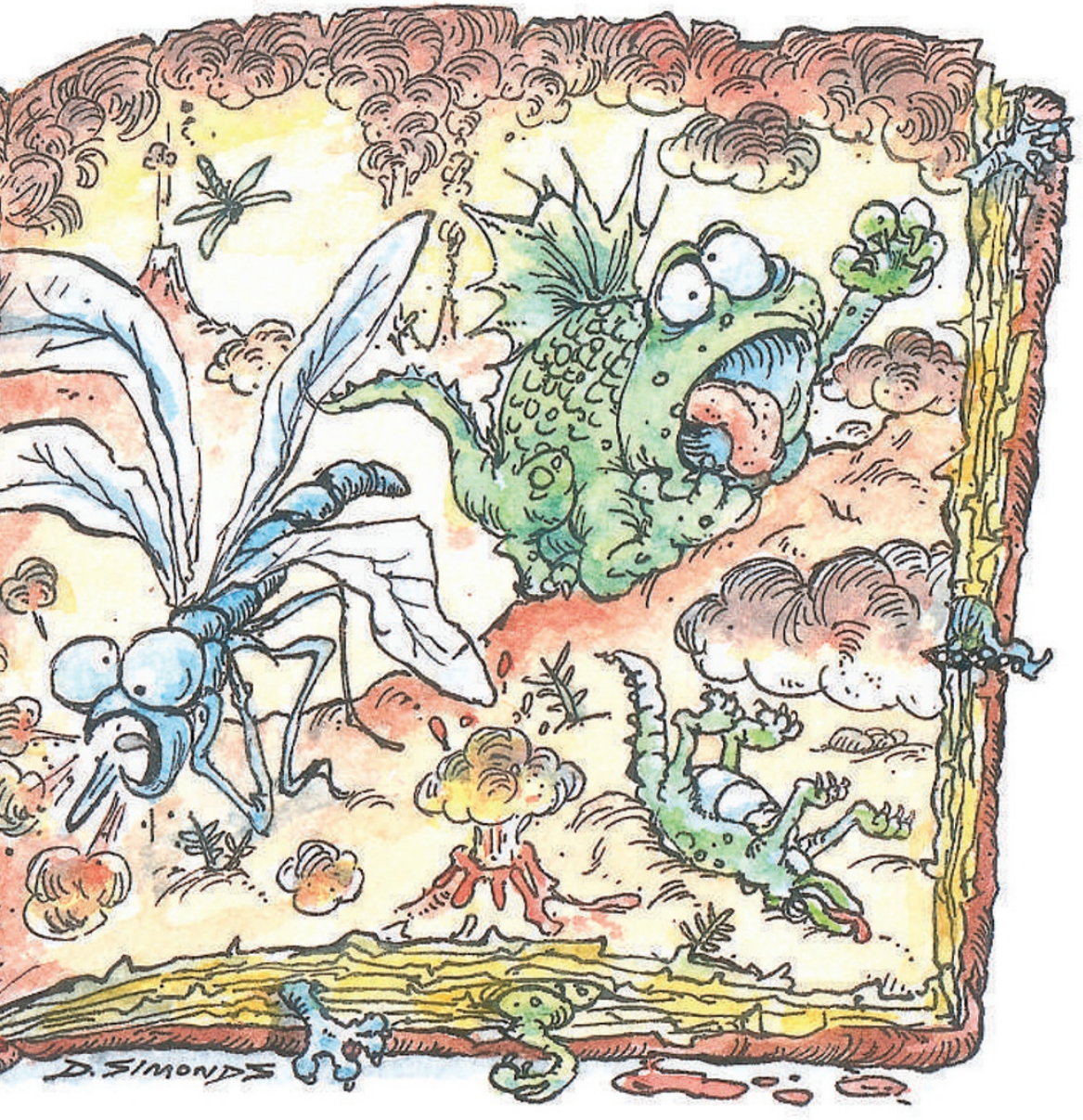

easily escape the worst of it," he says. And as with global warming, an excess of ultraviolet radiation does not seem to fit the pattern of survival that is actually seen. Living deep in the sea doesn't seem to have helped.

But better ways of breathing, which are often seen in creatures with a higher metabolic rate, did. In the sea, creatures with gills and an active internal circulation, such as snails, clams, crabs and fish, fared better than stationary filter feeders. A similar pattern holds on land, with groups that were not so good at pumping air through their respiratory systems - such as the giant dragonflies iconic of pre-Permian times - suffering disproportionately. These patterns focus attention not on harsher sunlight, but on tainted air.

\section{Oxygen collapse}

One possible factor is a worldwide dearth of oxygen. It used to be thought that today's oxygen level of $21 \%$ had remained fairly constant over geological time. But in the late 1980s, Robert Berner of Yale University in New Haven, Connecticut, shocked the establishment by arguing that in the Carboniferous period that preceded the Permian, 300 million years ago, the oxygen level had reached 30\% or more, and that it had then fallen dramatically to a mere $13 \%$ in the late Permian and the early part of the subsequent Triassic. But after a few refinements, Berner's models for this period have been widely accepted.

Berner blames the oxygen collapse on another spate of volcanism that predates the Siberian Traps by eight million years or so. The warming those eruptions triggered, he argues, would have brought about more arid conditions, drying out some of the coal swamps of the time. It had been the capacity of those swamps to bury organic carbon where it could not be respired back into carbon dioxide, which had accounted for the high oxygen levels. As the swamps dried out, less organic carbon got buried this way, and so more was respired back to carbon dioxide - using up oxygen in the process. Over millions of years the slower rate of carbon burial drew oxygen levels down to an unprecedented low point $\mathrm{t}^{5}$.

The falling oxygen levels Berner describes would have restricted the geographical range of many land animals ${ }^{6}$. Most animals have an 'altitude ceiling' above which they can't flourish (for humans it's 5.1 kilometres). As oxygen levels dropped in the later Permian, so these ceilings would have pressed down on the creatures beneath them. According to palaeontologist Peter Ward of the University of Washington in Seattle, for creatures that had evolved in a high oxygen world, modest hills of just a few hundred metres could have become impassable barriers.

In the oceans, too, the habitable zone would have shrunk as oxygen levels fell. Global warming would have made matters worse, as oxygen is less soluble in warm water than in cold. Such effects are still visible in the world today. This January a study of fish populations in the North Sea showed that, among eelpouts (Zoarcidae), the size of both populations and individuals shrinks when increased temperatures lessen the oxygen supply ${ }^{7}$.

Palaeontologist Richard Twitchett, at the University of Plymouth, UK, thinks that something similar happened in Permian times. His evidence comes from the species that seem to vanish at the end of the Permian, only to start cropping up again after a hiatus of millions of years - the 'Lazarus taxa'. A startling 70\% of the gastropods found in the mid-Triassic seem to have 'risen from the dead' in this way. Twitchett thinks that their populations became so small that random chance expunged them from the fossil record. Things didn't pick up for the gastropods until oxygen levels started to pick up, well into the Triassic ${ }^{8}$. And when they did re-emerge, they were smaller - they have something of Lilliput, as well as Lazarus, about them.

But for all this it is hard to pin the mass extinction proper on oxygen. From a physiological point of view, the species most likely to survive low oxygen would seem to be those

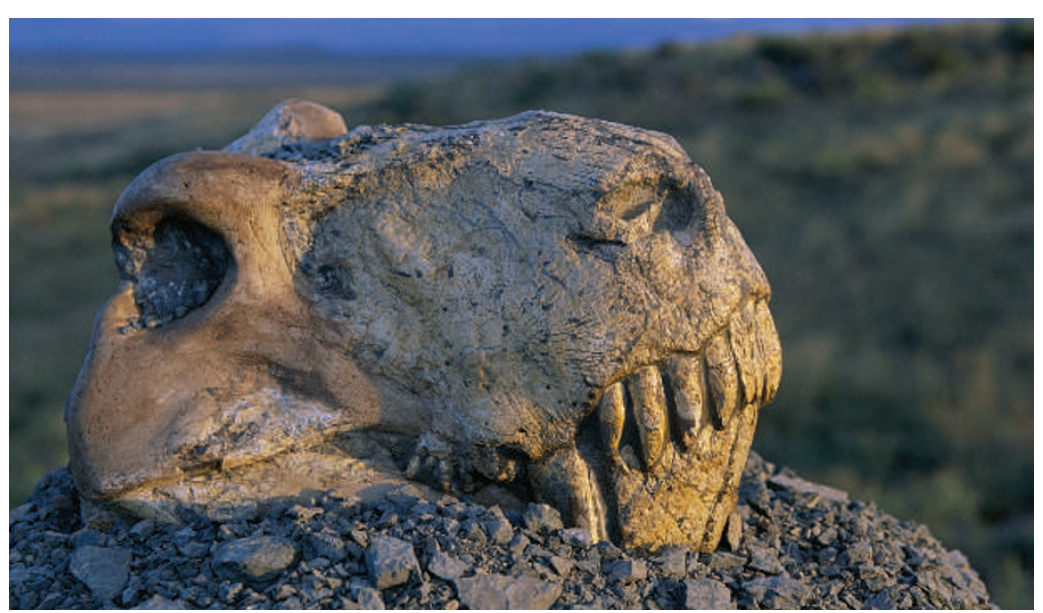

Extinction victim: Dinogorgon rubidgei, a mammal-like reptile. 
with a low metabolic rate - and yet the stationary filter feeders, which fit that bill, fared disastrously. And then there's the timing. The trends in atmospheric oxygen levels were slow, reflecting changes in the rate at which organic matter was buried over millions of years. By contrast, detailed analyses of the strata in which the fossils are preserved show that the extinction was abrupt, with most species disappearing in a few tens of thousands of years ${ }^{9}$. As Andrew Knoll, a palaeontologist at Harvard University in Boston, Massachusetts, puts it: "If you've got gradual changes taking place over millions of years, I'd expect organisms to adapt; but if the changes take place in 10,000 years, I'd bet on the environment to club them."

\section{Killer carbon}

Low oxygen must have placed life in a precarious position, but something else pushed it over the edge. And a good clue to the culprit is a series of unusual shifts in carbon isotopes found in strata worldwide, corresponding closely to the exact time of the extinction.

This series of spikes in the carbon-isotope level suggests that strange things were happening to the carbon cycle at this time. The anomalies - sudden upswings in the ratio of lighter carbon-12 to heavier carbon-13 - are too big to be explained by changes in the total amount of biomass (which tends to be carbon-12 rich). The most plausible explanation would be bursts of methane. But sea-floor methane hydrate reserves would not be up to the job. There are five distinct spikes in the record between the latter part of the Permian and the early Triassic. According to Jonathan Payne at Harvard University and his colleagues, although sea-floor hydrate reserves might account for one such spike, they could not be replenished quickly enough for a whole succession ${ }^{10}$.

Greg Retallack of the University of Oregon in Eugene points to a different source. In both the Siberian Traps and the earlier volcanism, lava rose to the surface through both carbonate rocks and coalfields. Hot lava passing through coal measures breaks down some of the heavy hydrocarbons into methane, and although this 'thermogenic' methane is not as light, isotopically speaking, as the stuff on the sea floors, it is light enough to explain the isotope spikes ${ }^{11}$.

At a time when oxygen levels were already stressing animal life, such large injections of methane, which would oxidize into carbon monoxide and carbon dioxide, could have killed animals through simple asphyxiation. As for the plants, Retallack points out that those that did the worst were in swamps, which were low in oxygen anyway, so their roots asphyxiated.

The need to deal with high levels of carbon dioxide could explain various aspects of the survivors' physiology, including subtleties at the molecular level. Knoll is intrigued by a subtle difference in pigment use between the squid-like ammonoids, which died out, and the creatures from which today's spiralshelled nautilus is descended. Animals use

\section{"Even if death doesn't get you right away, you're unlikely to have much spare energy for sex."}

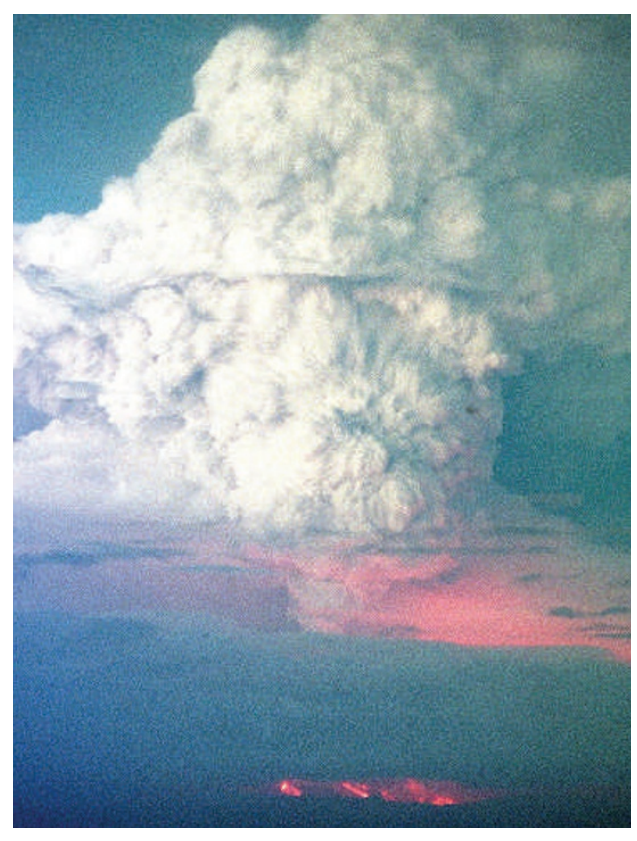

Eruptions, such as Hekla's, could cause ozone depletion. respiratory pigments such as haemoglobin to get oxygen from the lungs or gills to the tissues that need it, and to remove the resulting carbon dioxide. When carbon dioxide levels get too high, some such pigments will cease to work properly, unable to remove the bodily carbon dioxide with which they are encumbered or to pick up more oxygen. The nautilus, Knoll notes, has a pigment that deals well with high levels of carbon dioxide. The closest living relatives of the ammonoids, the coleoids - soft-bodied cephalopods such as squid and octopus - do not.

Their unhelpful pigments might not have been enough to doom the ammonoids - but as shell makers they had other problems too. One of the effects of increasing carbon dioxide is that sea water, like soil, becomes more acid. Shell formation, Knoll argues, is repressed if carbon dioxide levels cause organisms to lose control over their systems for dealing with such acidity. The groups least good at regulating acidity seem to have been particularly badly hit at the end of the Permian. So were those creatures that needed their shells to channel water over their gills.

\section{Sulphur survivors}

The case for a significant amount of asphyxia is strong. But global warming and low oxygen would have brought another deadly gas into play. Hydrogen sulphide is produced in vast quantities by bacteria that gain their energy from sulphate, and that thrive only in very low oxygen conditions. Today, these conditions are prevalent only in closed basins, most strikingly that of the Black Sea. But there's plenty of evidence to suggest that such conditions applied much more widely at the end of the Permian.

Lee Kump, a geochemist at Pennsylvania State University in University Park, argues that sulphidic deep waters could have crept higher and higher up the water column, killing everything they encountered and creating what is evocatively named a 'Strangelove ocean'. When they reached the surface they would have released poisonous gas straight into the air $^{12}$. Last year, biomarkers unique to 'green sulphur' bacteria, which make use of sulphide for photosynthesis and cannot tolerate oxygen, were found in some sediments from the end of the Permian, suggesting that oxygen-free waters got close enough to the surface for photosynthesis to take place ${ }^{13}$.

The effects of hydrogen sulphide escaping from the oceans would in all likelihood have been local, not global, and Beerling's models suggest that no plausible level of the gas could have damaged the ozone layer, as had been suggested. But it would have been another challenge for stressed ecosystems.

So with dangerously low atmospheric oxygen levels, ecosystems were compressed and fragmented. The deep oceans were largely uninhabitable. Land plants were dying back in the arid greenhouse climate, making food hard to come by. And then came the hammer blows of fate, the greatest volcanic outpourings in the history of our planet, releasing vast quantities of methane and carbon dioxide, raising global temperatures by $6^{\circ} \mathrm{C}$, and lifting the 
Strangelove conditions to the very surface.

Head for the hills and there's no oxygen; stay on the shores and you risk breathing hydrogen sulphide. High carbon dioxide levels sabotage your respiratory pigments and choke you from within. Even if death doesn't get you right away, you're unlikely to have much spare energy for sex. Population sizes fall; so do body sizes. Even for those that survive the immediate toxicity, slow extinction was likely over a few generations - the blink of an eye in geological terms.

And the resultant catastrophe shaped the rest of the planet's history. According to research by Peter Wagner and his colleagues at the Chicago Museum of Natural History in Illinois, life in the seas before the extinction was split roughly 50-50 between simple marine ecosystems dominated by sessile filter-feeders, such as today's sea lillies, and more complex systems in which larger numbers of species moved around and interacted. After the extinction and the subsequent recovery, complex ecosystems outnumbered simple ones by three-to-one ${ }^{14}$. That has remained pretty much the case ever since, the patterns of biodiversity reflecting the extinction bottleneck that a few creatures squeezed through with frantically fluttering gills.

The situation was similar on the continents. The hardiest group of reptiles was the cynodonts, from which mammals are descended. The squat, flat-faced Lystrosaurus, with its breathing aided by a bony palate separating the mouth from the nose and a barrel-chest with a muscular diaphragm to help deep breathing, went on to dominate the Triassic. Cynodonts also enjoyed the benefits of nasal turbinate bones.

Some turbinates are linked with fast metabolic rates in warm-blooded creatures, as they restrict water loss during rapid respiratory ventilation. In the early Triassic, though, they might have restricted water loss in hyperventilating animals on the verge of suffocation ${ }^{15}$. Other survivors included the archosaurs, which benefitted from breathing made easier by air sacs. Their descendants became the dinosaurs, birds and crocodiles ${ }^{16}$.

It's unlikely that any of these respiratory adaptations evolved in response to the suffocating conditions at end of the Permian; rather, the animals most likely to survive the disaster were those already adapted to deal with suffocating conditions on a daily basis - creatures used to burrowing on land, or scavenging in the stagnant muds of ocean shelves; or just those that came up trumps with an air-sac system that happened to be particularly good.

Take a deep breath, fill your lungs with a toxic brew of gases, gasp for the thin oxygen. Small wonder most life perished; wouldn't you? But your ancestors survived and repopulated the world in new ways that we still see

"Head for the
hills and there's
no oxygen;
stay on the
shores and you
risk breathing
hydrogen
sulphide."

around us today. The genetic memory of those times is etched in our physiology — and in the living fabric of our world.

Nick Lane is the author of Power, sex, suicide: Mitochondria and the meaning of life.

1. Kamo, S. L. et al. Earth Planet. Sci. Lett. 214, 75-91(2003).

2. Knoll, A. H., Bambach, R. K., Payne, J. L., Pruss, S. \& Fischer, W. W. Earth. Planet. Sci. Lett. 256, 295-313 (2007).

3. Benton, M. J. \& Twitchett, R. Trends Ecol. Evol. 18, 358-365 (2003)

4. Beerling, D. J., Harfoot, M., Lomax, B. \& Pyle, J. A. Phil. Trans. R. Soc. B 365, 1843-1866 (2007).

5. Berner, R. A. Geochim. Cosmochim. Acta 69, 3211-3217 (2005).

6. Huey, R. B. \& Ward, P. D. Science 308, 398-401 (2005).

7. Pörtner, H. O. \& Knust, R. Science 305, 95-97 (2007).

8. Twitchett, R. J., Krystyn, L., Baud, A., Wheeley, J. R. \& Richoz, S. Geology 32, 805-808 (2004).

9. Jin, Y. G. et al. Science $\mathbf{2 8 9}, \mathbf{4 3 2 - 4 3 6}(2000)$

10. Payne, J. L. et al. Science 305, 506-509 (2004)

11. Retallack, G. J. \& Krull, E. S. in Wetlands Through Time (eds Greb, S. \& DiMichele, W. A.) 249-268 (Geological Society of America, Boulder, Colorado, 2006).

12. Kump, L. R., Pavlov, A. \& Arthur, M. A. Geology 33, 397-400 (2005).

13. Grice, K. et al. Science 307, 706-709 (2006).

14. Wagner, P. J., Kosnik, M. A. \& Lidgard, S. Science 314, 1289-1292 (2006).

15. Berner, R. A., VandenBrooks, J. M. \& Ward, P. D. Science 316, 557-558 (2007).

16. O'Connor, P. M. \& Claessens, L. P. A. M. Nature 436, 253 (2005). 